\title{
Integrated modeling of seismic, gravity and magnetic data of Camamu Basin, Brazilian Eastern Margin: tectonostratigraphic framework, structural aspects, petroleum system, volcanic activity and crustal domains
}

Ana Cristina M. Q. Coelho ${ }^{1}$, Sergio L Fontes ${ }^{1}$, Emanuele F. La Terra ${ }^{1}$, Miguel Tupinambá ${ }^{2}$, Ved Maurya ${ }^{1}$, Gilmar Bueno ${ }^{3}$ and José Antônio Pereira ${ }^{1},{ }^{1}$ Observatório Nacional, ${ }^{2}$ Faculdade de Geologia/UERJ, ${ }^{3}$ Instituto de Geociências/ UFF

Copyright 2019, SBGf - Sociedade Brasileira de Geofísica

This paper was prepared for presentation during the $16^{\text {th }}$ International Congress of the Brazilian Geophysical Society held in Rio de Janeiro, Brazil, 19-22 August 2019.

Contents of this paper were reviewed by the Technical Committee of the $16^{\text {th }}$ International Congress of the Brazilian Geophysical Society and do not necessarily represent any position of the SBGf, its officers or members. Electronic reproduction or represent any position of the SBGt, its officers or members. Electronic reproduction or of the Brazilian Geophysical Society is prohibited.

\section{Abstract}

The Camamu Basin usually also referred to as CamamuAlmada basins in the literature is one of the sedimentary basins in the Brazilian Eastern Margin. The extent and influence of the volcanic rocks and the tectonics reactivations which may have affected the petroleum system of the basin are neither clearly understood. In this work, we mapped regional stratigraphic framework for the Camamu Basin. The seismic interpretation allowed us to identify the horizon surfaces of the sea floor, top Aptian, top Hauterivian, top Valanginian, salt, volcanic, and basement, thus contributing to the knowledge of the tectonostratigraphic evolution of the basin. We developed a workflow integrating seismic interpretation, well log tie and seismic velocity models, to construct potential field (aeromagnetics + satellite gravity) constrained 2D models. The chosen model infers the presence of volcanic and magmatic-underplating below the rifted extended margin of the Camamu basin.

\section{Introduction}

The Camamu basin is located on the Brazilian east coast, between the cities of Salvador and Ilhéus, Bahia state (Figure 1). Considering its emersed marine portions up to the bathymetric quota of 3,000 meters, the basin occupies a total area of $22,429 \mathrm{~km}^{2}$ and were formed during the rifting and subsequent development of the oceanic crust on the Brazil eastern margin. This basin is limited to the north by the Recôncavo-Tucano-Jatobá aborted rift that bends to the east because of the high Jacuípe basement. The rift was active during the Neocomian to Aptian, and was developed on the São Francisco Craton and its adjacent fold belts represented by Salvador-Itabuna-Itaju do Colônia and Araçuaí (Caixeta et al. 2007). These components of the basement had an important role in the evolution of this sedimentary basin as transversal fault structures due to events before the Neocomian rifting. Such anisotropy of the basement was reflected in hinge fault development, structural style faulting and, therefore, patterns of sedimentation in the rift and pos-rift sections of the basin. The main rift faults occur with N-S orientation in the Camamu basin, and with a NE-SW trend in the northern part of the basin. The main pattern of the major faults and basin hinges was inherited from the Itaju do Colônia-Itabuna-Salvador fold belt. This regional structure was named the Taipus Mirim Accommodation Zone. In the north of the Camamu Basin, there is a fault transfer zone on the rift, with NW-SE trend correlated with the Salvador shear zone, which deflects to the northwest of the Itabuna-Salvador-Curuça belt. During the Aptian age, in the north of the Taipus Mirim accommodation zone, the Camamu Basin played the role of a divisor of transitional sedimentation in the Almada and Camamu basins (Gontijo et al. 2007). In Camamu, dominated fluvialdeltaic systems and restricted marine evaporites in shallow lakes formed above the rift fault rotation blocks. During the Albian age, the Camamu Basin displayed an extensive shallow water limestone platform that extended to near the paleo coast and is related to a basement high. In the basement of the Camamu rift basin, there are two main lineaments: the Itaju do Colônia and the Salvador shear zones that are correlated to the rift transfer zones, the Taipus Mirim Accommodation Zone and the Salvador Transfer Zone, respectively. These basement lineaments had a long history of tectonic reactivation during the Paleoproterozoic (Transamazonic Orogeny) and Precambrian ages (Brasiliano Orogeny). For the Taipus Mirim accommodation zone, the control would be given by a major lineament with a NE-SW trend, which developed in the Paleoproterozoic as a transfer zone to accommodate the initial attempt to break up the São Francisco-Congo Craton, forming, as a result, the Paramirim aborted rift. This basement lineament was reactivated as a major dextral shear zone during the Brasiliano Orogeny, resulting in the Araçuai-West Congo fold belt, which bordered the southern edge of São Francisco-Congo Craton. In the Upper Cretaceous, the separation of the São Francisco and Congo Cratons reactivated those basement shear zones as rift transfer zones which controlled and separated the Camamu and Almada rift basins (Barbosa et al. 2003).

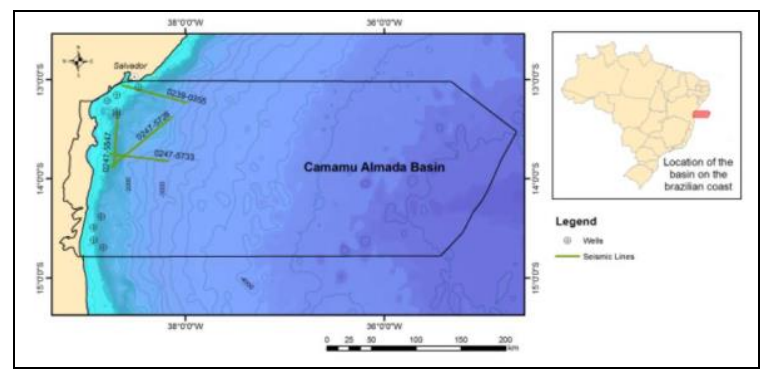

Figure 1. Location map of Camamu basin with seismic lines distribution. 


\section{Basement Control}

The Camamu and Almada basins were installed along a cratonic bridge between the São Francisco and Congo cratons (Barbosa et al. 2003). The proximal structural domain is the Itabuna-Salvador-Curuçá belt. It is composed by paleoproterozoic tonalites and granulites in tectonic slices separated by high angle east dipping reverse and oblique faults with NNE strike (Figure 2). In the belt it is common to find layered mafic to ultramafic complexes that increase the density and magnetic susceptibility of the basement. Neoproterozoic anorogenic (or post tectonic) alkaline intrusives are aligned along a NE trending Itaju do Colonia shear zone. To the North, the Salvador shear zone runs from the interior to the coast in the NW direction.

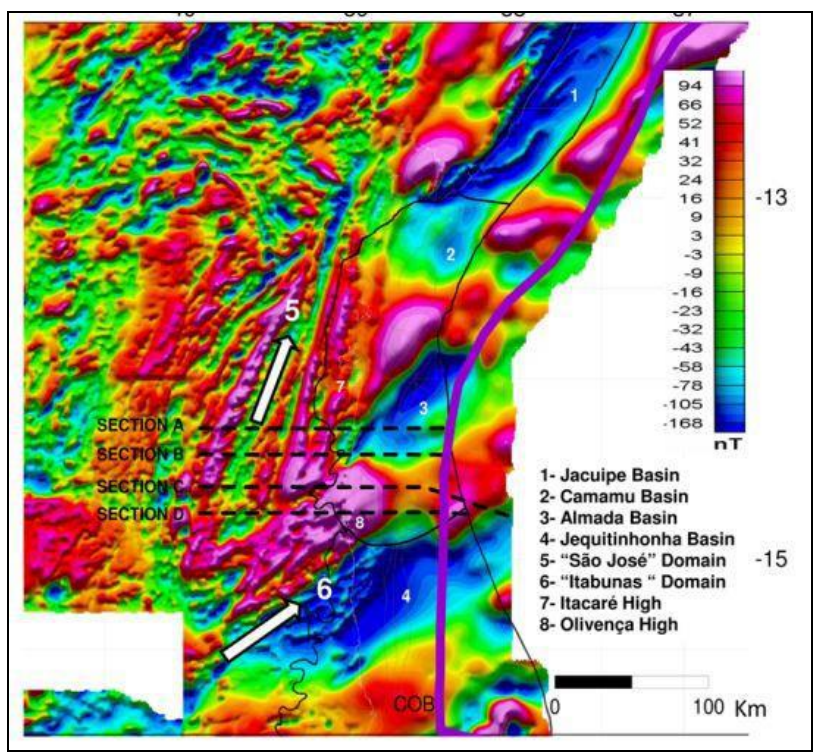

Figure 2. Almada Basin magnetic anomalies reflecting the control of the Itabuna-Salvador-Curuçá belt. Itabuna (NE) and São José (NNE) domains are main structural directions delimited by Gordon et al (2013).

\section{Basement Control in the rift stage}

The basement structures were reactivated during the rift tectonics and it seems still active in the Cenozoic. East dipping faults perform tectonic hinges between NNE halfgrabens (Gordon et al. 2013) or tectonic domains (Ferreira et al. 2007). The distal basins lie in an ultraextended continental crust or even oceanic crust, and the total sedimentary thickness can reach $6,000 \mathrm{~m}$. As discussed by Blaich et al. (2010), the sedimentary pile is not as typical as in rifted continental crust, with progressive crustal thinning over an extensive distance towards oceanic crust. On the contrary, thick syn-rift sedimentary basins are directly deposited on thinned crystalline continental crust. Along the tectonic hinges listric faults apparently detach the lower crust, and the high-strained tectonics prevent the formation of thick volcanic piles (Gordon et al. 2013).

\section{Post-rift tectonics and volcanism - basement} reactivations

Although the basin evolved in a magma-poor environment, post-rift volcanism and tectonics are widespread. Ferreira et al. (2007) demonstrated that the Salvador and Itaju do Colonia shear zones acted as accommodation zones during the main phases of basin infilling and our seismic interpretations corroborate it.

No apparent seamounts are known offshore Camamu basin, but strong magnetic anomalies are not clearly related to basement rocks. The volcanic structures crosscut a large proportion of the sedimentary pile, and some of them could evolve in the Neogenes.

\section{Petroleum System}

Caixeta et al. (2007) considered just a geographical boundary for the Camamu-Almada basins once that there was not a geological feature between them, observing a continuity structural trend. Gontijo et al. (2007) suggested the Taipus High as a speculative basement boundary, and latter Ferreira et al. (2007) defined Taipus Mirim Accommodation Zone (ZATM) as a heritage basement feature and established the geological boundary that controlled the rift and post-rift sedimentation in both basins. The ZATM produced substantial difference of 1.0kilometer depth between juxtaposed basements, which implies in Almada Basin an Aptian rift thicker than that observed in Camamu Basin. Additionally, is possible to observe the entire Cretaceous section and halokinese in Almada Basin. The rift shows segmented development seaward from Berriasian-Valanginian age onshore to Aptian age offshore. This behavior generated depocenters of different ages with sedimentation of potential source rocks in each one. The structural prerift/rift plays are the most common successful in the Camamu Basin while Tertiary turbidites stratigraphic plays are speculated in the Almada Basin.

The hydrocarbon generation modeling indicates that most of the oil was generated by the end of the rift phase (Barremian-Aptian). Kerogen transformation ratios range from $10-20 \%$ nearby the shallow water to $100 \%$ in the deep areas (Gonçalves et al., 2000). The Morro do Barro Formation main source rock of the basin can be correlated to Candeias Formation at Recôncavo Basin and Feliz Deserto Formation at Sergipe and Alagoas subbasins, all of them deposited during rift phase (Caixeta et al., 2007).

The hydrocarbon exploratory efforts directed to CamamuAlmada basins overcome 120 wells, most of them located onshore/shallow water and where several oil/gas discoveries were made.

Two petroliferous systems are recognized for Camamu and Almada basins: 1- Morro do Barro (rift)-Sergi (pre-rift) by the 1-BAS-64 oil accumulation (Gonçalves et al., 2000) and the Manati gas field; 2- Morro do Barro (rift)-Rio de Contas (rift) confirmed by 1-BAS-97 oil accumulation (Mello et al., 1995). 


\section{Seismic Interpretation}

Four 2D seismic lines were analyzed in Camamu Basin. The interpretation of the seismic horizons was based in both well and seismic data correlation, according to the lithostratigraphic markers present, which represent the location of the main limits observed and described in the composite log of the well.

The interpretation consisted in the mapping of the main stratigraphic horizons identified, based on prior knowledge regarding the stratigraphic succession of the area, continuity of the seismic reflectors, individualization of packages with similar seismic facies, and structural factors such as faults, salt, and volcanism.

In the study area of the Camamu Basin were interpreted the horizons Sea Floor, Top Aptian, Top Hauterivian, Top Valanginian, Salt, Volcanic, and Basement. In the Figure 3 are shown the location map, the original seismic line and the seismic line interpreted.

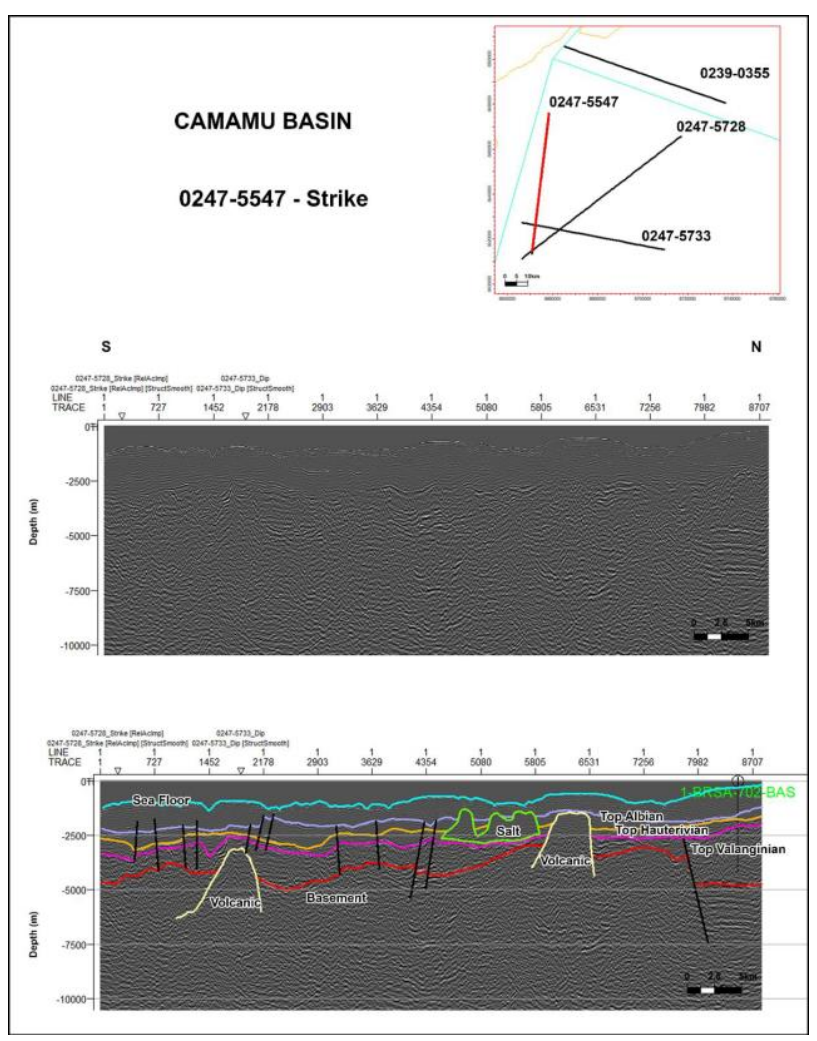

Figure 3. Seismic line 0247-5547 in depth. Data original amplitude (above) and seismic line interpretation (below).

\section{Seismic Attribute}

The main seismic data features can be highlighted by the extraction of seismic attributes, to improve or quantify the characteristics of interest for interpretation, difficult to identify in the original seismic data in amplitude (Chopra; Marfurt, 2007).

The seismic attribute corresponds to any mathematical measure of interest, derived from seismic data (Taner, 2001) such as measures of time, amplitude, and frequency (Sheriff, 2002).
The workflow for seismic interpretation and stratigraphic analysis was based on attributes derived from processed seismic data. In this work, used tecVa, first derivative, second derivative attributes, that highlighted significant geological features such as salt domes and volcanic rocks.

The volume amplitude technique (tecVa) generates seismic sections that reflect subsurface geology using a set of attributes (RMS, Remove bias and Phase Shift). The tec $\mathrm{Va}$ is a widely used attribute in the exploration workflow, for the identification of seismic sequences, stratigraphic units and geological unconformities (Bulhões; Amorim, 2005).

In this work, we used three attributes for the composition of tecVA: RMS amplitude that removes the carrier frequency, displaying just the geological information. This information is a result of the amplitude anomaly values, that allows the recognition of unconformities and faults; Remove bias, that removes the deconvolution, and Phase shift, controlling the phase of the seismic data. It makes the high impedance contrasts stronger, and consequently emphasizes the difference between lithology and textures.

The application of the attribute allowed highlighting the main structures of the basin and to assist in the seismic interpretation.

The Figure 4 display of volcanic rocks in seismic lines 0247-5733 improve for the attribute applied.

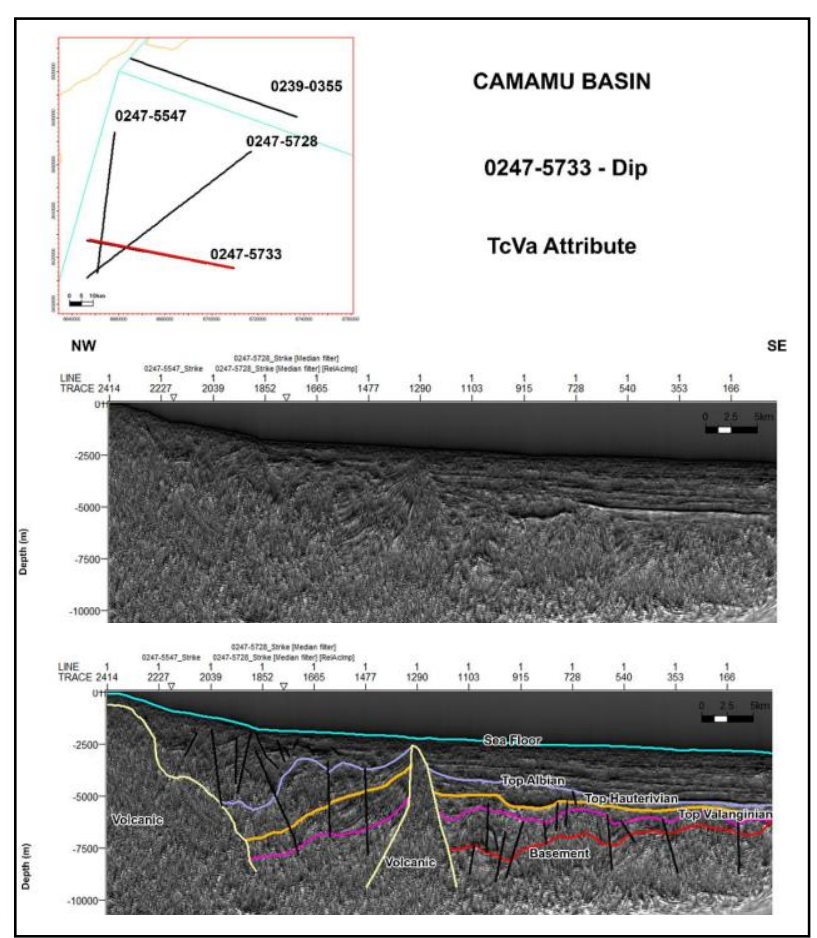

Figure 4. Seismic line 0247-5733 in depth. TecVa Attribute with featured volcanic interpretation.

The first derivative consists in computing a phase shift of $90^{\circ}$ for seismic traces of the input seismic volume. 
A first derivative is useful for quality check for the signal consistency, stratigraphic analysis, facies estimation, improve reflector sharpness and improve the correlation between seismic data and well log data (Zeng, 2005a). In seismic section (Figure 5) is shown the volcanic highlighted.

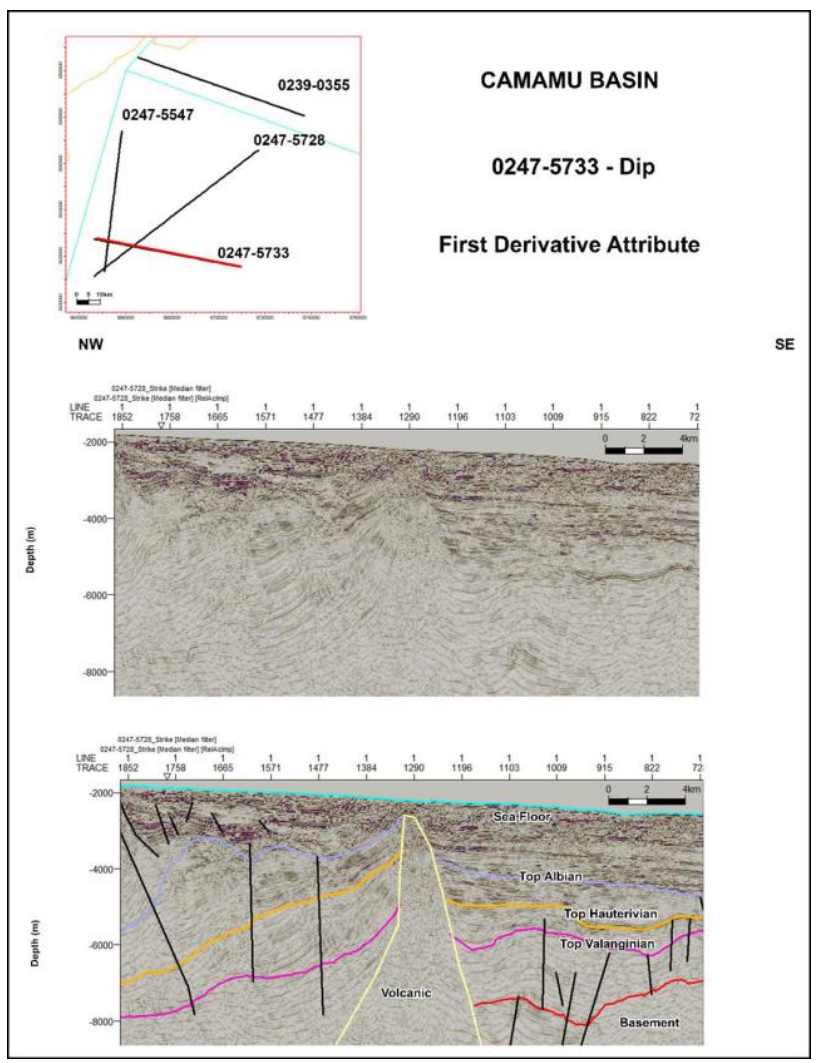

Figure 5. Seismic line 0247-5733 in depth. First Derivative Attribute with featured volcanic interpretation.

Second derivative attribute is method applied to precision structural interpretation. Usually, the bandwidth of the interpreted seismic data does not exhibit enough continuity or resolution for a satisfactory interpretation. In these cases, the second computation of the input seismic data can help. When the first derivative is generated, its phase is rotated by 90 degrees negative, as the second derivative is generated, the phase of the seismic data is rotated by 180 degrees negative.

In seismic section (Figure 6) the salt dome and volcanic rocks were highlighted, besides major geological structures interpreted.

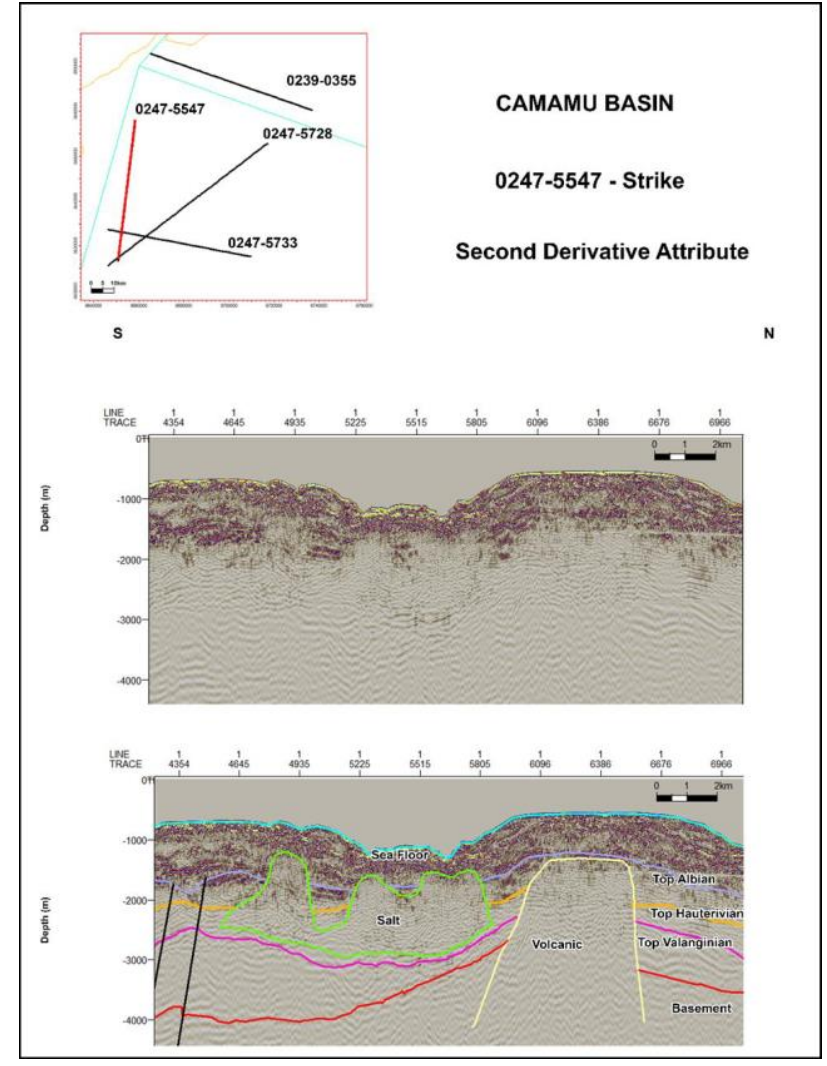

Figure 6. Seismic line 0247-5733 in depth. Second Derivative Attribute with featured salt and volcanic interpretation.

\section{Integration of Gravimetric and Magnetics with Seismic interpretation}

Main sedimentary layers in dip direction for 0247-5733 (Figure 7) were included from the 2-D seismic interpretation (all the features from the coincident 2-D seismic lines were discussed in seismic section). These layers include Eocene/Paleocene (Non-consolidated sediments), Hauterivian, Albian, Valanginian. Moho depth for starting model was taken from the Moho obtained from 3-D inversion of Bouguer gravity. For oceanic crust, we included a density of $2.75 \mathrm{~g} / \mathrm{cm}^{3}$ to optimize the fits on regional scale. Finally, we changed the depth to basement and Moho variation to optimize the fits on the integrated 2D model (Fig. 3.2). We also added volcanics also found in seismic section $\left(2.85 \mathrm{~g} / \mathrm{cm}^{3}\right)$ along with the rifted margin of the basin, still unable to explain the regional magnetic high above the rifted margin. To explain it, we added a magmatic layer with high density $\left(3.4 \mathrm{~g} / \mathrm{cm}^{3}\right)$ and high susceptibility (0.009 in cgs units). In fact, it provides a possible evolution path for the shallow volcanics and some authors explain it by a kind of shallow Moho reflector (Blaich et al., 2011). The final optimized RMS error are $\sim 4.2$ and 4.8 , respectively, for gravity and magnetic data after adjusting the density and susceptibility values, shape of transitional crust features through 2D modeling. We vary both density and susceptibility values smoothly through joint inversion to optimize the fits. Susceptibility varies laterally for crustal rocks from continent-ocean transition. Fits improved by adding the offshore extent of the Camamu basin up to depths of 7-10 km, consistent with the regional geology. 


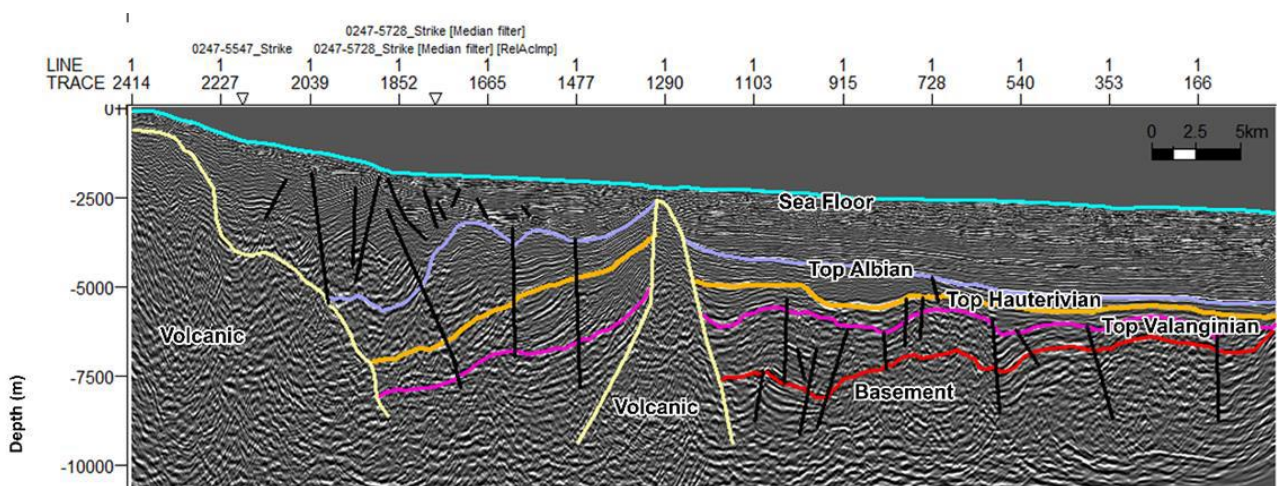

SEISMIC LINE 0247_5733

CAMAMU ALMADA BASIN

Fri Jan 18 12:45:412019
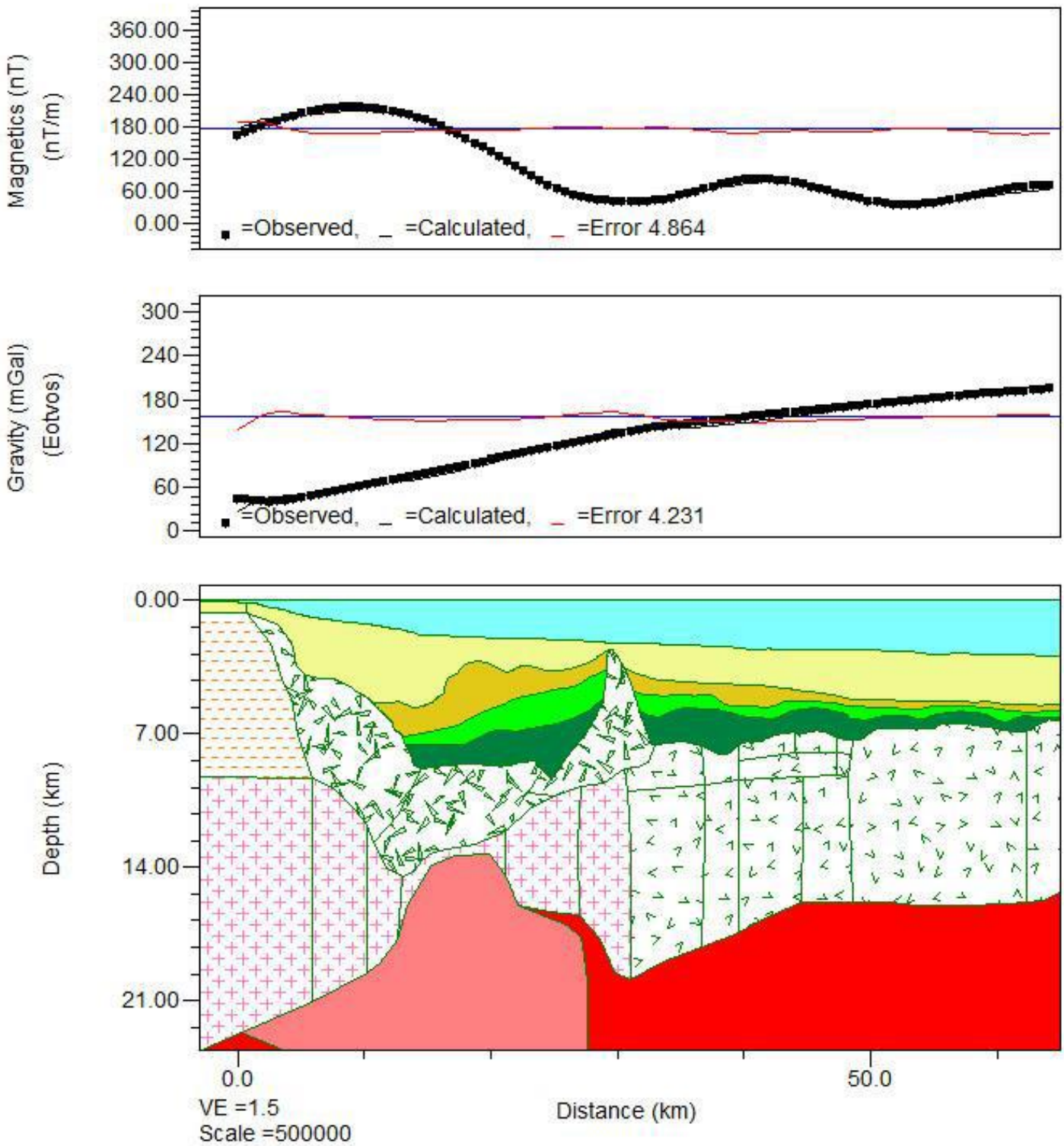

Figure 7. 2D Model creation of Dip Line profile 0247-5733 
The crust is $\sim 35 \mathrm{~km}$ thick beneath the continent and shallows up to $16 \mathrm{~km}$ below oceanic domain over a lateral extent of $\sim 50 \mathrm{~km}$. For transition zone prior to COB, susceptibility varies laterally, however, density don't show any variation. Density varies regionally from the continental crust, to the oceanic crust. Interestingly, behavior of extended rifted margin is unique in the Camamu basin as it becomes very thin below the depocenter of the rift axis, and thickens when move away from the rift axis on both sides. Joint $2 \mathrm{D}$ model infers the presence of volcanics and magmatic-underplating below the rifted extended margin of the Camamu basin was highlighted.

\section{Conclusions}

For the analysis, we used four 2D seismic, well logs, aeromagnetic and satellite gravity data.

The seismic interpretation allowed us to identify the horizon surfaces of the sea floor, top Aptian, top Hauterivian, top Valanginian, salt, volcanic, and basement, thus contributing to the knowledge of the tectonostratigraphic evolution of the basin.

The results from seismic attributes were obtained by using tecVA, first derivative and second derivative attributes, that highlighted significant geological features as salt domes and volcanic rocks cross-cutting the main geological formations.

The basement structures were reactivated during the rift tectonics and it seems that is still active in the Cenozoic.

The distal basins lie in an ultra-extended continental crust or even oceanic crust, and the total sedimentary thickness can reach $6,000 \mathrm{~m}$.

Two-dimensional potential field model was created constraining the basin features using seismic interpretation. The model inferred a presence of volcanic and magmatic-underplating below the rifted extended margin of the Camamu basin. The demarcation of COB was possible features through integrated $2 \mathrm{D}$ modeling of gravity, magnetic and seismic data. The COB Transition Zone is marked by the presence of rocks with oceanic and continental affinities.

The hydrocarbon generation modeling indicates that most of the oil was generated by the end of the rift phase (Barremian-Aptian).

Two petroliferous systems are recognized for Camamu and Almada basins: 1- Morro do Barro (rift)-Sergi (pre-rift) and the Manati gas field; 2- Morro do Barro (rift)-Rio de Contas (rift).

The relationship between the petroleum system within the basin and both the basement/volcanics control and postrift reactivation are ongoing research.

\section{Acknowledgments}

We thank Sinochem Petróleo Brasil Ltda. for supporting this research. The geophysical data (seismic lines, well logs, aeromagnetics) were acquired from ANP. ACMQC and SLF acknowledge the support of the Institutional Training Program and research fellowship from CNPq.

\section{References}

Barbosa, J. S. F., Sabate, P. \& Marinho, M. M. 2003. O Craton do São Francisco na Bahia: uma sintese. Revista Brasileira de Geociencias, 33, 3-6.

Bulhões, E. M.; Amorim, W. N. de. 2005. Princípio da sismocamada elementar e sua aplicação à técnica volume de amplitudes (tecva). In: Society of Exploration Geophysicists and Brazilian Geophysical Society. 9th International Congress of the Brazilian Geophysical Society \& EXPOGEF, Salvador, Bahia, Brazil.

Blaich, Olav A., Jan Inge Faleide, and Filippos Tsikalas. 2011. Crustal breakup and continent-ocean transition at South Atlantic conjugate margins." Journal of Geophysical Research: Solid Earth 116.B1.

Caixeta. J. M., Milhomem, P. S., Witzke, R. E., Dupuy, I. S. S. \& Gontijo, G. A. 2007. Bacia de Camamu. Boletim de Geociências da Petrobras V.15, n.2, 455-461.

Chopra, S.; Marfurt, K. Curvature attribute applications to 3d surface seismic data. The Leading Edge, Society of Exploration Geophysicists.

Ferreira, T. S.; Caixeta, J. M.; Lima F. D. 2007. Controle do embasamento do rifteamento das bacias de Camamu e Almada. Boletim de Geociências da Petrobrás, 17 (1): 69-88.

Gonçalves, F. T. T., Bedregal, R. P., Coutinho, L. F. C. \& Mello, M. R. 2000. Petroleum System of the CamamuAlmada Basin: A Quantitative Modeling Approach. In: M. R. Mello \& B. J. Katz, eds. Petroleum Systems of South Atlantic Margins: AAPG Memoir 73, p.257-271.

Gontijo, G. A., Milhomem, P. S., Caixeta. J. M., Dupuy, I. S. S. \& Menezes, P. E. L. 2007. Bacia de Almada. Boletim de Geociências da Petrobras V.15, n.2, 463-473.

Gordon, A.C., Mohriak, W.U. and Barbosa, V.C., 2013. Crustal architecture of the Almada Basin, NE Brazil: an example of a non-volcanic rift segment of the South Atlantic passive margin. Geological Society, London, Special Publications, 369(1), pp.215-234.

Mello, M. R., Gonçalves, F. T. T., Netto, A. S. T.,Amorim, J. L. \& Witzke, R. E. 1995. Application of the petroleum system concept in the assessment of exploration risk the Camamu Basin example, offshore Brazil. 40 Congr. Intern. Soc. Bras. Geofísica. Rio de Janeiro, Brazil.

Sheriff, R. E. 2002. Encyclopedia dictionary of applied geophysics. Society of Exploration Geophysicists, p. 22.

Taner, M. T. 2001. Seismic attributes. 26. V. [S.I.]: CSEG recorder.

Zeng, H., Backus, M. 2005 a. Interpretive advantages of 90o-phase wavelets: Part 1 - Modeling. Geophysics, Vol.7; No.3, C7 - C15. 